\title{
Reconstructive surgery of the aortic valve
}

\author{
Cirurgia reconstrutiva da valva aórtica
}

José Teles de MENDONÇA ${ }^{1}$, Marcos Ramos CARVALHO ${ }^{1}$, Rika Kakuda da COSTA ${ }^{1}$, Roberto Cardoso BARROSO $^{1}$, José Edivaldo dos SANTOS $^{1}$, Sérgio Costa TAVARES FILHO ${ }^{2}$

RBCCV 44205-658

\section{Abstract}

Objective: Lacking an ideal valve substitute and motivated by the good results of mitral valve repair since 1990, we faced with determination aortic valve reconstruction surgery. The objective of this paper is to show our experience with this procedure.

Method: Between January of 1990 and December of 2001; 136 aortic valve repair surgeries were performed. Seventyfive $(55.1 \%)$ of the patients were female and the ages ranged from 4 to 70 years (mean $23.3 \pm 1.2$ years). Every patient had rheumatic valve disease and insufficiency was the most prevalent type (108 patients $-\mathbf{7 9 . 4 \%}$ ), followed by double aortic lesion in $16(11.7 \%)$ patients and stenosis in $12(8.8 \%)$. The surgical techniques used were: subcommissural annuloplasty in $74(54.4 \%)$ patients, commissurotomy in $38(27.9 \%)$, cusp extension with pericardium in $17(\mathbf{1 2 . 5 \%})$, substitution of one cusp in $2(1.4 \%)$, cusp suspension by annuloplasty in 37 $(27.2 \%)$ and Valsalva sinus remodeling in $27(19.8 \%)$. The surgery exclusively involved the aortic valve in 57 (41.9\%) patients and was associated in 79 (mitral valve replacement in 12 , mitral repair in 65 , coronary artery bypass grafting in 1 and pulmonary commissurotomy in 1 ).

Results: Hospital mortality was $2.2 \%$ and $22(16.2 \%)$ patients underwent a new surgery during the follow-up period (57.7 + 3.5 months).

Conclusions: Aortic valve repair is a safe surgical procedure that can be used in an increasing number of patients with promising results.

Descriptors: Aortic valve, surgery. Aortic valve insufficiency, surgery. Aortic valve stenosis, surgery.
1 - Medicine Department, Federal University of Sergipe. Hospital de Clínicas Dr. Augusto Leite

2 - Hospital São Lucas, Aracaju, Sergipe

Correspondence address:

José Teles de Mendonça.

Av. Prof. Acrísio Cruz, 445

Ed. Mont Blanc Apto 1101

Aracaju, Sergipe

CEP 49020-210
Article received on October, 2002 Article accepted on September, 2003 


\section{Resumo}

Objetivo: Por falta de um substituto valvar ideal e motivados pelos bons resultados obtidos com a plástica da valva mitral, passamos, a partir de 1990 , a encarar, com determinação, também a cirurgia reconstrutiva da valva aórtica. O objetivo deste trabalho é apresentar nossa experiência com este tipo de procedimento.

Método: De janeiro de 1990 a dezembro de 2001, foram realizadas 136 plásticas da valva aórtica. Setenta e cinco $(55,1 \%)$ pacientes eram mulheres e a idade variou de 4 a 70 $\operatorname{anos}(x=23,3 \pm 1,16$ anos). Todos eram portadores de disfunção valvar de origem reumática, sendo a insuficiência o tipo mais freqüente (108 pacientes-79,4\%), seguida pela dupla lesão (16 pacientes - 11,7\%) e pela estenose (12 pacientes - $8,8 \%$ ).Os procedimentos empregados na reconstrução foram: anuloplastia subcomissural em $74(54,4 \%)$ pacientes; comissurotomia em 38 (27,9\%); ampliação de cúspide com

\section{INTRODUCTION}

Although surgical therapy of valvar dysfunctions is one of the oldest chapters in cardiac surgery, there are many doubts about the efficiency of the diverse procedures utilized until today.

The replacement of a diseased valve for a prosthesis, a simple procedure that is easy standardized, has not reached, until the present, an acceptable degree of safety and reliability. This frustration is greater in younger patients, when the incidence of complications makes the procedure of much concern [1-9].

The lack of an ideal replacement valve and the good results achieved with reconstruction of atrioventricular valves serve as an incentive for some surgeons to become attracted to the challenge of reconstructive surgery of the aortic valve [10-15]

The aim of this study is to present our experience with this procedure, above all emphasizing its applicability and the immediate and long-term results, with respect to mortality and the necessity of reoperation.

\section{METHOD}

From January to December 2001, 136 patients were submitted to aortic valve reconstructive surgery. Seventyfive $(55.2 \%)$ were female and $61(44.8 \%)$ were male. The age ranged from 4 to 70 years (mean $23.3 \pm 1.2$ years and median 17.5 years). All were suffering from rheumatic valve disease, with insufficiency the most common type (108 patients $79.4 \%)$. A double injury was found in $16(11.7 \%)$ patients and stenosis in $12(8.8 \%)$.

All the patients were operated on using cardiopulmonary bypass, hypothermia at $30^{\circ} \mathrm{C}$ and isothermal sanguineous pericárdio bovino em 17 (12,5\%); substituição de uma cúspide em 2 (1,4\%); suspensão de cúspide por plicatura em 37 (27,2\%) e remodelação do seio de Valsalva em $27(19,8 \%)$. A operação foi realizada apenas na valva aórtica em $57(41,9 \%)$ pacientes e associada em 79 (troca de valva mitral em 12; plástica mitral em 65; revascularização do miocárdio em 1 e comissurotomia pulmonar em 1).

Resultados: Três $(2,2 \%)$ pacientes faleceram na internação e $22(16,2 \%)$ necessitaram de reoperação durante o seguimento ( $x-57,7 \pm 3,5$ meses).

Conclusões: A cirurgia reconstrutiva da valva aórtica é um procedimento seguro, pode ser realizado em um número significativo de pacientes e os resultados são promissores.

Descritores: Valva aórtica, cirurgia. Insuficiência da valva aórtica, cirurgia. Estenose da valva aórtica, cirurgia.

cardioplegia* applied in the coronary ostia, soon after clamping, and repeated at 30 minute intervals.

The aortic valve was approached by means of oblique aortotomy, directed to the non-coronary Valsalva's sinus and mitral valve, when treated by conventional left atriotomy.

The operation involved the aortic valve in isolation in 57 $(41.9 \%)$ of the patients and it was associated with other procedures in $79(58.1 \%)$. The associated procedures included mitral valve surgery in 77 patients (plastic in 65 and valve replacement in 12), coronary artery bypass grafting in one patient and pulmonary commissurotomy in one patient.

The procedures employed in the reconstruction of the aortic valve were: commissural annuloplasty in 74 (54.4\%) patients; commissurotomy in 38 (27.9\%); enlargement of the cuspid with bovine pericardium in 17 (12.5\%); substitution of the cuspid with neo-cuspid of bovine pericardium in $2(1.4 \%)$; elevation of the cuspid in 64 patients, thinning of the cuspid in $18(13.2 \%)$ and decalcification in 3 $(22 \%)-($ Figures 1 and 2). Elevation of the cuspid was achieved by plication in $37(27.2 \%)$ and through noncoronary Valsalva sinus remodeling in 27 (19.8\%).

The valvar function test was performed in the intraoperative period, using as a base the visual aspect of the repaired valve (shape, opening, mobility and coaptation of the cuspids) and by an evaluation of the blood flow to the left ventricle. In the cases in which the mitral valve was approached, evaluation was by direct visualization of the regurgitation (in this condition reconstruction of the aortic valve was the first procedure to be performed), or by the filling or not of the left ventricle, after aortic declamping. The echocardiogram, despite being a very useful aid, for logistic reasons was rarely utilized. Only refluxes that were considered minor were accepted. If this result was not initially 
achieved, the valve was approached again and repaired or substituted.

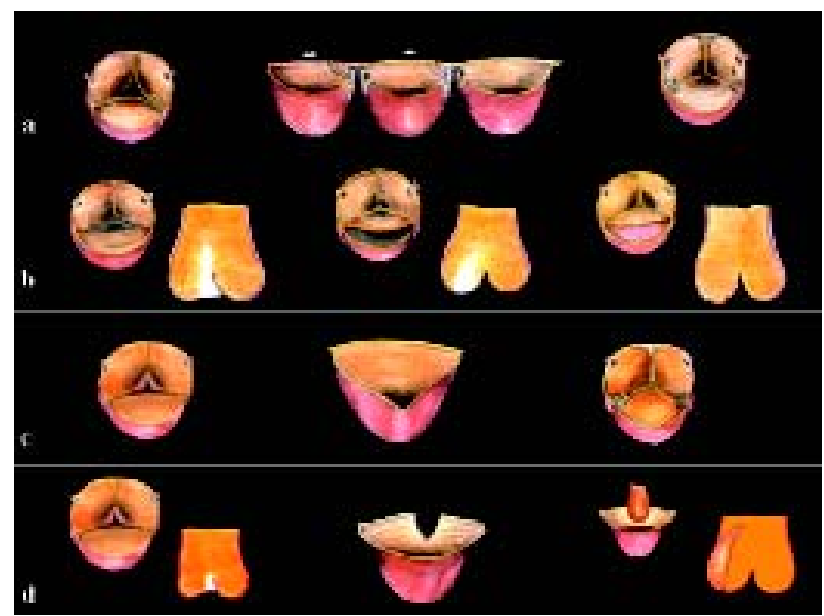

Fig. 1 - Schematic representation of the technical procedures utilized in aortic valve reconstruction: a) commissural annuloplasty; b) enlargement of the cuspid; c) elevation of a cuspid by plication and d) elevation of a cuspid for remodeling of the Valsalva's sinus

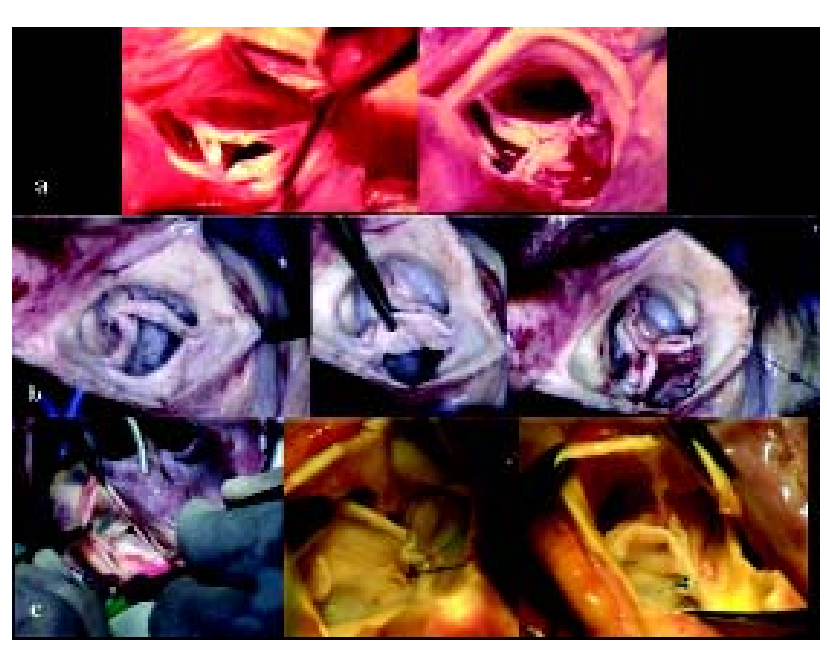

Fig. 2 - Surgical photographs of some reconstructive procedures of the aortic valve: a) commissural annuloplasty; b) enlargement of the cuspid and c) elevation of a non-coronary cuspid by plication

Before hospital release, the patients were submitted to an echocardiographic evaluation and subsequently, referred back to their original cardiologists with recommendations of follow-up evaluations at every six months.

The data were collected directly from the patients' records (when seen by physicians from the department) or by specific questionnaires sent to the respective physicians of the patients or even by direct consultation of the patients by letter or telephone.
The student t-test was employed to compare nonmatched values and the Kaplan-Meier method for tracing of the reoperation-free probability curves.

\section{RESULTS}

The mean time of cardiopulmonary bypass was $88.2 \pm$ 6.7 minutes for aortic valve surgeries in isolation and 107.1 \pm 2.9 minutes for associated procedures ( $p$-value $<0.05$ ). The aortic clamping time was $67.8 \pm 6.2$ minutes for plastic surgery in isolation and $85.5 \pm 2.5$ minutes for operations with associated procedures ( $\mathrm{p}$-value $<0.05$ ). The operative mortality was $2.2 \%$ (3 patients) owing to causes not related to the surgery.

The follow-up period ranged from 37 days to 144.6 months (mean $57.7 \pm 3.5$ months). There was a late mortality due to endocarditis of the mitral prosthesis. Twenty-two $(16.2 \%)$ patients required reoperations, which occurred without fatalities in a follow-up period of between 37 days and 9 years (mean $3.5 \pm 0.6$ years). The actuarial reoperationfree curve gave a probability of $81.3 \pm 3.8 \%$ and $59.8 \pm 9.5 \%$ at 5 and 10 years respectively (Figure 3 ).

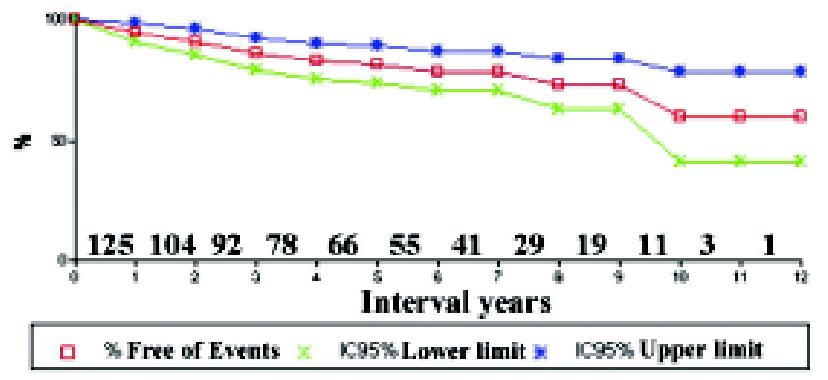

Fig. 3 -Actuarial curve: free of reoperation.

\section{COMMENTS}

Owing to the lack of an ideal valvar substitute and, in particular, motivated by the good results initially achieved using mitral valve reconstructive surgery [1-9] and, consequently the aortic valve [10-13], we decided, from 1990, to give priority to repair surgery. Thus, prostheses were utilized only for cases in which the structural valvar alterations did not allow any type of repair [16].

Reconstructive surgery, different to the use of prostheses (of easy technical standardization), demands not only training but also a great artistic sensitivity of the surgeon to return to the deformed valve, its mobility and shape, thereby restoring its function. Thus, it is clear, that reconstructive surgery is a procedure that, apart from requiring determination and patience, demands a certain amount of resignation of the doctor to follow a learning curve. Also a great quantity of humility is needed to establish 
a progressive selection of cases depending on the degree of complexity of the defect. Additionally, the surgeon must know when to retreat and implant a prosthesis if the result achieved by plastic surgery is not considered ideal.

In the functional reconstruction of the aortic valve, a series of procedures can be employed that basically aim at increasing the area of blood flow, on one hand, and correct regurgitation by perfect coaptation of the cuspids on the other. The first group includes commissurotomies, decalcification or thinning of thickened cuspids, increasing the mobility of the valvar leaflets [10,17]. In the second group, a series of procedures whose greatest justification is to permit adequate coaptation of the three cuspids to distribute the forces and dissipate stress. Among these, the following can be utilized: a) commissural $[18,19]$ and circumferential annuloplasty [10]; b) enlargement of the cuspids: increasing the free edge $[11,20-24]$ or inserting a graft between the annulus and the base of the cuspid $[12,13,15]$; c) cuspid replacement [25-27]; d) suspension of the cuspid by commissural plication [28,29]; triangular resection $[10,14]$ or remodeling of the Valsalva sinus **. Figures 1 and 2 illustrate some of these procedures.

The choice of technique is not always simple and frequently the surgeon is required to use more than one procedure. The initial approach should start with a detailed analysis of the functional components of the aortic valve, to analyze: the Valsalva sinuses, annuli, cuspids and commissures; trying to identify the defects and establish a strategy to correct them.

Annuloplasty was employed when insufficiency was due to dilation of the valvar annulus with well-preserved cuspids. In these cases, the commissural annuloplasty was always used.

When there was fibrotic retraction of one or more of the cuspids, the choice procedure has been enlargement of the affected cuspid with insertion of a bovine pericardium graft. Always when a cuspid is enlarged, an associated annuloplasty is performed on the adjacent commissures of the repaired cuspid.

An alternative technique in cases of severe fibrotic retraction of the non-coronary cuspid, which often occurs in rheumatic disease, would be a more aggressive annuloplasty of the commissures associated with the retracted cuspid. This would make the cuspid rudimentary or exclude it completely, transforming the tricuspid aortic valve in a bicuspid valve [30].

In these cases, special attention should be paid to the diameter of the annulus, especially in young and small patients, so that the valve does not become stenotic. The preference has been to enlarge the retracted cuspid, as it is known that acting in this way improves the anatomical and functional recovery of the treated valve. With this, there are expectations of better long-term results as was demonstrated by DURAN et al. [15] and BAHNSON et al. [23], who stressed that the plastic surgery should copy, as far as possible, the normal anatomy.

For the enlargement or substitution of the cuspids, several types of materials have been used, starting with ivalon sponge utilized by LILLEHEI in 1958 [20], fresh [21, $22,24,25]$ or preserved bovine pericardium [27, 31, 32], heterologous pericardium treated with glutaraldehyde [11$13,15,26]$ and homographs [33].

The availability, low cost and facility in the handling of autologous and heterologous pericardium makes them the most commonly used materials. It is unclear which of them provides the best long-term results [24].

Thin bovine pericardium $(0.21$ to $0.25 \mathrm{~mm})$ is preferred. During the procedure, an incision was made at the base of the cuspid to be lengthened (in the majority of cases noncoronary) and the free edge is drawn to reach the other two, taking care that all are at the same height. The graft should be a little larger than the created orifice and the suture made with fine monofilament thread (polypropylene 6-0), turning the edges to the ventricular face in a way to create a perfect 'shell'. It is believed that by acting in this manner, the effects of retraction of the graft will be compensated, as even if it occurs there will still be contact between the cuspids.

Another feared complication with the use of pericardium is calcification, which may occur, principally in young patients. Performing the enlargement as suggested, calcification happens without the loss of contention and the valve, even with the cuspid static, can last for a long time.

A common anatomic finding in young patients with rheumatic aortic insufficiency, specifically in those with involvement of the mitral valve, is pure and simply prolapse of the non-coronary cuspid. In these cases two alterations which were attributed to the traction of the prolapsed cuspid are observed: correction of the Valsalva sinus and the bringing together of the respective commissural points.

This type of defect has been corrected using a technique which was named by the authors as Valsalva sinus remodeling **. This consists of opening the sinus as far as the cuspid, followed by the insertion of a bovine pericardium graft in a way of restoring the shape of the sinus and separating the commissures and, with this, elevate the cuspid and guarantee an adequate coaptation (Figure 1). A plication of the cuspid is utilized beside the commissures [28,29] when only prolapse exists without these aforementioned findings.

Conquering the prejudice and increasing the interest in aortic valve reconstruction surgery, its application will increase as the surgeon acquires experience with the procedure. Currently, a growing number of patients have benefited from this surgical technique. CARPENTIER, in the 1980 s, believed that only $5 \%$ of the insufficient aortic 
valves could be repaired [10]. In 1991, DURAN et al. [15] recovered $42.6 \%$ of the insufficient rheumatic aortic valves, operated on between July 1988 and July 1990. Our decision to preserve aortic valves was made in January 1990 and, as yet, $32.2 \%(136 / 423)$ of the rheumatic valves consecutively approached were reconstructed. The percentage of repaired valves grew significantly with the reduction of age at the time of operation. From $60.4 \%$ (81/134) for patients with ages less than or equal to 20 years it increased to $68.7 \%(55 / 75)$ for under 16-year-olds, expressing a determination to preserve the aortic valve in this age group where the use of prostheses is more problematic.

Although the follow-up time of the patients submitted to aortic valve reconstructive surgery, in the majority of the published cohorts, is still short, the results until now are encouraging [14,15,24,27,34,35-37]. Data from this work, a hospital mortality rate of $2.2 \%$ and probability of remaining reoperation-free of $81.3 \pm 3.8$ at five years and $59.8 \pm 9.5$ at ten years, are in harmony with the literature and help to consolidate the expectations in relation to aortic valve reconstructive surgery.

\section{CONCLUSIONS}

Aortic valve reconstructive surgery is a safe procedure and can be performed in a significant number of patients with rheumatic aortic disease.

The results achieved are promising enabling the procedure to be recommended for a greater number of patients, above all young patients, when the use of a prostheses is frequently more problematic.

\section{Footnotes}

* Cardioplegia performed with blood at the temperature of the perfusate.

\section{**Original technical procedure}

\section{BIBLIOGRAFHIC REFERENCES}

1. Carpentier A, Chauvaud S, Fabiani JM, Deloche A, Relland J, Lessana A et al. Reconstructive surgery of mitral incompetence: ten-year appraisal. J Thorac Cardiovasc Surg 1980; 79: 338-48.

2. Shore DF, Wong P, Paneth M, Buckley MJ. Results of mitral valvuloplasty with a suture plication technique. J Thorac Cardiovasc Surg 1980; 79: 349-57.

3. Antunes MJ, Magalhães MP, Colsen PR, Kinsley RH. Valvuloplasty for rheumatic mitral valve disease: a surgical challenge. J Thorac Cardiovasc Surg 1987; 94: 44-8.
4. Ribeiro EJ, Carvalho RG, Brofman PR, Mozaki N, Almeida RM, Ferreira MA et al. Cirurgia reconstrutiva da válvula mitral. Arq Bras Cardiol 1983; 41: 341-3.

5. Gregori Jr F, Takeda RT, Silva SS, Façanha LA, Ribeiro IA, Aquino WF et al. Sete anos de experiência com plastia da valva mitral. Arq Bras Cardiol 1986; 47: 269-74.

6. Eloy R, Ferreira Jr A, Carvalho H, Brito JC, Tadeu E, Nery AC et al. Cirurgia orovalvar na criança: experiência de 135 casos. Rev Bras Cir Cardiovasc 1986; 1 (2): 24-8.

7. Brofman PR. Cirurgia conservadora da válvula mitral em pacientes jovens: técnica cirúrgica e resultados. [Tese de doutorado]. São Paulo: Faculdade de Medicina da Universidade de São Paulo, 1986.

8. Lobo Filho G, Martins JM, Oliveira FM, Memória Jr JMF, Pimenta F, Araújo JAR et al. Cirurgia reconstrutiva da válvula mitral pela técnica de Carpentier. Rev Cir Cardiovasc 1988; 1: 16-8.

9. Braile DM, Ardito RV, Pinto GH, Santos JLV, Zaiantchick M, Souza DRS et al. Plástica mitral. Rev Bras Cir Cardiovasc 1990; 5: 86-98.

10. Carpentier A. Cardiac valve surgery: "the French correction". J Thorac Cardiovasc Surg 1983; 86: 323-37.

11. Yacoub M, Khaghani A, Dalla A. Aortic valve replacement using unstented dura or calf pericardium erly and medium term results. In: Bodnar E, Yacoub M, eds. Biological and bioprosthesis valves. New York: York Medical Books; 1986. p. 684-90.

12. al Fagih MR, al Kasab MR, Ashmeg A. Aortic valve repair using bovine pericardium for cusp extension. J Thorac Cardovasc Surg 1988; 96: 760-4.

13. Bongiovani HL, Ribeiro PJF, Évora PRB, Brasil JCF, Reis CL, Sgarbieri RN. Plastia valvar aórtica por ampliação de válvula com pericárdio bovino: nota prévia. Rev Bras Cir Cardiovasc 1988; 3: 130-3.

14. Cosgrove DM, Rosenkranz ER, Hendren WG, Bartlett JC, Stewart WJ. Valvuloplasty for aortic insufficiency. J Thorac Cardiovasc Surg 1991; 102:571-7.

15. Duran C, Kumar N, Gometza B, al Halees Z. Indications and limitations of aortic valve reconstruction. Ann Thorac Surg $1991 ; 52: 447-54$.

16. Mendonça JT, Wanderley Neto J, Carvalho MR, Costa RK, Franco Filho E, Costa GB et al. Cirurgia valvar na infância: um novo espectro de ação. Rev Bras Cir Cardiovasc 1992; $7: 174-9$.

17. Cosgrove DM, Ratliff NB, Schaff HV, Edwards WD. Aortic valve decalcification: history repeated with a new result. Ann Thorac Surg 1990; 49: 689-90. 
18. Cabrol C, Cabrol A, Guiraudon G, Bertrand M. Le traitement de I'insuffisance aortique par I'annuloplastie aortique. Arch Mal Coeur Vaiss 1966; 59: 1305-12.

19. Ankeney JL, Tzeng TS, Liebman J. Surgical therapy for congenital aortic valvular stenosis: a 23 - year experience. J Thorac Cardiovasc Surg 1983; 85: 41-8.

20. Lillehei CN, Gott VL, Dewall RA, Varco RL. The surgical treatment of stenotic or regurgitant lesions of the mitral and aortic valves by direct vision utilizing a pump oxigenator. J Thorac Surg 1958; 35: 154-91.

21. Ross DN. Surgical reconstruction of the aortic valve. Lancet 1963; 1: 571-4.

22. Björk VO, Hulquist. Teflon and pericardial aortic valve prosthesis. J Thorac Cardiovasc Surg 1969; 8: 126-32.

23. Bahnson HT, Hardesty RL, Baker Jr. LD, Brooks DH, Gall DA. Fabrication and evaluation of tissue leaflets for aortic and mitral valve replacement. Ann Surg 1970; 171: 939-47.

24. Kalangos A, Beghetti M, Baldovinos A, Vala D, Bichel T, Mermillod B et al. Aortic valve repair by cusp extension with the use of fresh autologous pericardium in children with rheumatic aortic insufficiency. J Thorac Cardiovasc Surg 1999; 118: 225-36.

25. Edwards WS. Aortic valve replacement with autogenous tissue. Ann Thorac Surg 1969; 8: 126-32.

26. Batista RJV, Dobrianskij A, Comazzi Jr. L, Lessa Neto LT, Rocha G, Sartori F et al. Clinical experience with stentless pericardial aortic monopatch for aortic valve replacement. J Thorac Cardiovasc Surg 1987; 93: 19-26.

27. Duran CM, Gometza B, Kumar N, Gallo R, Martin-Duran R. Aortic valve replacement with freehand autologous pericardium. J Thorac Cardiovasc Surg 1995; 110: 511-6.
28. Starr A, Menashe V, Dotter D. Surgical correction of aortic insufficiency associated with ventricular septal defect. Surg Gynecol Obstet 1960; 111: 71-6.

29. Trusler GA, Moes CA, Kidd BS. Repair of ventricular septal defect with aortic insufficiency. J Thorac Cardiovasc Surg 1973; 66: 394-403.

30. Fontes RD, Salerno HD, Hijo AVEE, Najjar A, Scala LCN, Farah MCK et al. Remodelação cirúrgica da valva aórtica. Rev Bras Cir Cardiovasc 2001; 16: 212-7.

31.Carpentier A. Le concept de bioprothèses et son application à la fabrication de matérieaux biologiques. [PhD Tesis ]. Paris, Orsay, 1975.

32. Liao K, Frater RW, LaPietra A, Ciuffo G, Ilardi CF, Seifter E. Time-dependent effect of glutaraldehyde on the tendency to calcify of both autografts and xenografts. Ann Thorac Surg 1995; 60: S343-7.

33. Katz MR, Barnhart GR, Johnson D, Lower RR. Homograft replacement of single aortic valve cusps: 22 years follow-up. J Card Surg 1988; 3: 279-303.

34. Bernal JM, Fernandez-Vals M, Rabasa JM, Gutierrez-Garcia F, Morales C, Revuelta JM. Repair of nonsevere rheumatic aortic valve disease during other valvular procedures: is it safe? J Thorac Cardiovasc Surg 1998; 115: 1130-5.

35. Neves Júnior MT, Pomerantzeff PMA, Brandão CMA, Grinberg M, Barbero-Marcial M, Stolf NAG et al. Plástica da valva aórtica em pacientes portadores de insuficiência aórtica: resultados imediatos e tardios. Rev Bras Cir Cardiovasc 1996; 11: 155-60.

36. Ahn H, Kim KH, Kim YJ. Midterm result of leaflet extension technique in aortic regurgitation. Eur J Cardiothorac Surg 2002; 21:465-9.

37. Grinda JM, Latremouille C, D'Attellis N, Berribi A, Chauvaud $\mathrm{S}$, Carpentier A et al. Triple valve repair for young rheumatic patients. Eur J Cardiothorac Surg 2002; 21: 447-52. 